\title{
Selective control of rangeland grasshoppers with prescribed fire
}

\author{
LANCE T. VERMEIRE, ROBERT B. MITCHELL, SAMUEL D. FUHLENDORF, AND DAVID B. WESTER
}

Authors are Rangeland Scientist, USDA-ARS, Fort Keogh Livestock and Range Research Laboratory, 243 Fort Keogh Rd., Miles City, Mont. 59301; Range scientist, USDA-ARS, Wheat, Forage and Sorghum Unit, 344 Keim Hall, E.C., Univ. Nebr., Lincoln, Nebr. 68583; Associate Professor, Plant and Soil Sciences Department, Oklahoma State University, Stillwater, Okla.74078-6028; and Professor, Department of Range, Wildlife, and Fisheries Management, Texas Tech University, Lubbock, Tex. 79409-2125. Vermeire and Mitchell were formerly Research Assistant and Associate Professor, Department of Range, Wildlife, and Fisheries Management, Texas Tech University.

\section{Abstract}

Grasshoppers (Orthoptera: Acrididae) are considered among the most damaging rangeland pests, but are necessary for the survival of many wildlife species. Most grasshoppers species are innocuous, but control with insecticides is non-discriminatory among species. The objectives were to evaluate the effects of prescribed burning on the abundance and biomass of grasshoppers and to determine if species could be selectively controlled with prescribed fire. Twenty-four, 4-ha sites were selected in a sand sagebrush-mixed prairie near Woodward, Okla. and blocked by pasture. Plots were randomly assigned fall-, spring-, or nonburned treatments within block with 4 replications per treatment for each of 2 years. Grasshopper biomass and abundance were sampled in late July and early August by sweeping with canvas beating nets. Specimens were weighed to the nearest $0.1 \mathrm{mg}$ and identified to species. Fire treatments had no effects on the total abundance or biomass of grasshoppers across species, with about 10 grasshoppers weighing $4,090 \mathrm{mg}$ per 150 sweeps. Fire effects on the 4 most common species were variable and could be explained by the biology of the insects. Melanoplus bowditchi and M. flavidus were unaffected by fire treatment. Hesperotettix viridis is sensitive to damage to its host plants and was reduced about $88 \%$ by fire in either season. Ageneotettix deorum abundance was $65 \%$ lower on fall-burned plots. We hypothesize the reduction occurred because the species' eggs are laid near the soil surface and exposed to the heat of passing fire. Fire prescriptions may be developed to target species-specific vulnerabilities and reduce pest grasshoppers while maintaining the food base for grasshopper predators.

Key Words: Acrididae, Ageneotettix deorum, Artemisia filifolia, Hesperotettix viridis, Melanoplus bowditchi, pest management

Grasshoppers (Orthoptera: Acrididae) are considered among the most detrimental invertebrate pests throughout the world because of the damage they inflict on agricultural crops and forage resources (Watts et al. 1989). Forage consumption rates of individual grasshoppers are relatively small, but they waste nearly as much as they consume and at high densities, can substantially reduce forage availability for livestock and herbivorous

The authors wish to thank Eddie Wilson of the Oklahoma Department of Wildlife Conservation and Phil Sims and Bob Gillen of the Southern Plains Range Research Station for their hospitality and support.

Manuscript accepted 15 Apr. 03.

\section{Resumen}

Los saltamontes (Orthoptera: Acrididae) son considerados entre las plagas mas dañinas de los pastizales, pero son indispensables para la sobrevivencia de muchas especies de fauna silvestre. La mayoria de las especies de saltamontes son inofensivas, pero el control con insecticides es no discriminatorio entre estas especies. Los objetivos fueron evaluar los efectos de la quema prescrita sobre la abundancia y biomasa de saltamontes asi como determinar si las especies podrian ser selectivamente controladas con la quema prescrita. Veinticuatro sitios de 4 ha fueron selecionados en una pradera mixta de sand sagebrush cercana a Woodward, Okla. y fueron bloqueados por potrero. Las parcelas recibieron aleatoriamente los siguientes tratamientos: quema de otoño, quema de primavera y sin quema dentro de cada bloquedo con 4 repeticiones por tratamiento por cada 2 años. La biomasa y abundancia de los saltamontes fue muestreada a finales de Julio y a principios de Agosto barriendo con redes de lienzo. Los especimenes fueron pesados al cercano $0.1 \mathrm{mg}$ e identificados a nivel de especie. Los tratamientos con fuego no tuvieron efecto sobre la abundancia y biomasa total entre especies, con 10 saltamontes pesando 4,090 mg por cada 150 barridas. El resultado de los tratamientos con fuego fue variable entre las 4 mas comunes especies y esto puede ser explicado por la biologia de los insectos. Melanoplus bowditchi y $M$. flavidus no fueron afectadas por el fuego. Hesperotettix viridis fue sensitiva, siendo reducida alrededor de un $\mathbf{8 8 \%}$ debido al daño de recibido por las plantas hospedadoras en ambas temporadas. La abundancia de Ageneotettix deorum fue $65 \%$ mas baja en las parcelas con quema de otoño. Nosotros hipotetizamos que la reduccion ocurrio debido a que las especies depositan sus huevos sobre la superficie del suelo y por lo tanto estan expuestas al calor del fuego. Prescripciones para el uso del fuego pueden ser desarrolladas par las especies objetivo tomando en cuenta las vulnerabilidades especificas de las especies y de esta forma reducir las especies de saltamontes plaga mientras se mantiene disponibilidad de alimento para las especies depredadoras de saltamontes.

wildlife. Hewitt and Onsager (1983) estimated that more than $20 \%$ of the forage in the western United States is lost annually to grasshoppers.

Control efforts with insecticides have been controversial because of the costs, short treatment life, and potential effects on non-target species (Blickenstaff et al. 1974, Watts et al. 1989). Although grasshoppers compete with other herbivores and some 
species are agricultural pests, they also provide an important seasonal food source for many wildlife species, particularly birds. Insecticides used for grasshopper control have had few direct effects on birds (McEwen et al. 1972, Stromborg et al. 1984, George et al. 1995). However, with grasshopper crude protein concentrations of 50 to $70 \%$ (Ueckert et al. 1972, DeFoliart 1975), predators may have difficulty overcoming the insects' absence following large-scale control. Grasshoppers are a large component of summer and fall diets for gallinaceous birds (Davis et al. 1975, Doerr and Guthery 1983) and along with other insects, have been considered necessary for the survival and growth of chicks (Johnson and Boyce 1990).

Of the 600 grasshopper species in the United States, only about a dozen frequently occur at high densities. Selective control of these destructive species would maintain the food base for insectivores while protecting the forage base for herbivores. Prescribed fire is a potential alternative to chemical control that may allow more specific targeting of pest species. Direct mortality is likely if burns are conducted when grasshoppers are in a wingless nymph stage, or if eggs are exposed to lethal temperatures. Variations in grasshopper hatching dates and methods of egg deposition may allow fire prescriptions to be directed at species-specific control. Our objectives were to evaluate the effects of fall and spring prescribed burning on the abundance and biomass of grasshoppers and to determine if species could be selectively controlled with prescribed fire.

\section{Methods and Materials}

\section{Study Area}

The study was conducted about $15 \mathrm{~km}$ northwest of Woodward, Okla. $\left(36^{\circ} 34^{\prime} \mathrm{N}\right.$, $99^{\circ} 34^{\prime} \mathrm{W}$, elev. $625 \mathrm{~m}$ ) on the Hal and Fern Cooper Wildlife Management Area. The site is a mixed prairie shrubland on undulating sandhills with slopes of 1 to $12 \%$. Mean annual precipitation is 572 $\mathrm{mm}$ with $70 \%$ occurring as rain during the growing season (Apr-Sep). Mean monthly temperatures range from $1^{\circ} \mathrm{C}$ in January to $29^{\circ} \mathrm{C}$ in July (Unpublished data, USDA-ARS).

All data were collected on Deep Sand ecological sites. The dominant soils are Pratt loamy fine sands (sandy, mixed, mesic Lamellic Haplustalfs) except on the tops of dunes where Tivoli fine sands (mixed, thermic Typic Ustipsamments) are common (Nance et al. 1960). Sand sagebrush (Artemisia filifolia Torr.) was the principal woody plant with 20 to $50 \%$ canopy cover across most of the area. Isolated thickets of sand plum (Prunus angustifolia Marsh.) were also present. The herbaceous component was dominated by little bluestem [Schizachyrium scoparium (Michx.) Nash], gramas (Bouteloua spp. Lag.), western ragweed (Ambrosia psilostachya D.C.), sand bluestem (Andropogon hallii Hack.), sand lovegrass [Eragrostis trichodes (Nutt.) Wood], and Texas croton [Croton texensis (Kl.) Muell. Arg.]. Pre-treatment herbaceous standing crop was 2,800 to $3,500 \mathrm{~kg}$ $\mathrm{ha}^{-1}$. Pastures were lightly stocked (2l-23 AUD ha ${ }^{-1}$ ) with cattle annually from April to September.

\section{Methods}

We selected 24 , 4-ha plots with the restrictions that they were similar in vegetative composition and located at least 1.6 $\mathrm{km}$ apart. Plots were blocked by pasture and randomly assigned fall-burned, springburned, or non-burned treatments within blocks, with 4 replications per burn treatment for each of 2 years. No restrictions were placed on cattle grazing within pastures during the grazing season. Fall burns were conducted on 16 November 1999 and 14 November 2000. Spring burns were applied 17 April 2000 and 12 April 2001. Air temperature was about $20^{\circ} \mathrm{C}$, with 6to $12-\mathrm{km}$ hour $^{-1}$ winds, and 27 to $45 \%$ relative humidity during the burns. Herbaceous fuels and weather conditions allowed continuous fire fronts and combustion was nearly complete for fine fuels and some 10-hour fuels. Below-ground structures of numerous sand sagebrush plants were blackened below the soil surface.

Grasshoppers were sampled between 1100 and 1600 hours with light $\left(8-19 \mathrm{~km}\right.$ hour $\left.{ }^{-1}\right)$ winds and hot $\left(32-38^{\circ} \mathrm{C}\right)$, clear $(<10 \%$ clouds) weather conditions at the end of July 2000 and in mid-August 2001. Sampling was conducted by sweeping a standard canvas beating net $(38-\mathrm{cm}$ diameter) through the top layer of vegetation, making a $180^{\circ}$ arc at each step. Each plot was sampled with 150 sweeps from 3 randomly located 50 -sweep transects. After each set of 50 sweeps, net contents were dumped into 3.8-liter plastic bags that were sealed then placed in a dark plastic bag. Specimens were placed on ice after each plot was sampled then frozen until sorted in the lab. Adult and late-instar grasshoppers were counted, weighed to the nearest $0.1 \mathrm{mg}$, and identified to species using keys (Helfer 1953, Coppock 1962, Otte 1981, 1984, Pfadt 1988).
Weather and cattle grazing were monitored throughout the study since both factors have been shown to affect grasshopper populations (Fielding and Brusven 1990, Onsager 2000). Temperature and precipitation data were obtained from a local weather station on the Southern Plains Experimental Range $10 \mathrm{~km}$ from the study site. Mean daily air temperatures from April through September were converted to degree-days above $17.8^{\circ} \mathrm{C}$, based on a threshold for nymphal development (Putnam 1963).

Data were analyzed as a randomized block design with analysis-of-variance (SAS Institute 1985). Models for grasshopper abundance, biomass, and abundance of common individual species or species complex included terms for year, block within year, burn treatment, and the interactions. When differences occurred, means were separated using Fisher's Protected Least Significant Difference (Steele and Torrie 1980). An alpha level of 0.10 was used for all tests.

\section{Results and Discussion}

Weather conditions were favorable for grasshoppers both years of the study, with mean growing- and dormant-season air temperatures of about 23 and $6^{\circ} \mathrm{C}$, respectively. The period from April through September provided ample opportunity for nymphal development with 1,058 and 1,091 degree-days above $17.8^{\circ} \mathrm{C}$ in 2000 and 2001 , respectively. Annual precipitation was near normal, but growing-season precipitation for 2000 and 2001 was 9 and $26 \%$ below the 62-year mean (Fig. 1). Grass utilization by cattle was less than $20 \%$ on non-burned plots, but cattle were strongly attracted to plots burned in spring or fall, utilizing more than $80 \%$ of the grasses (Vermeire 2002). Despite heavy grazing pressure, total herbaceous standing crop on burned plots was $1,460 \mathrm{~kg} \mathrm{ha}^{-1}$ (Vermeire 2002).

Grasshopper abundance across species was greater in 2000 than 2001 at 13 and 8 grasshoppers per 150 sweeps $(\mathrm{P}<0.03)$, but was not affected by burn treatment $(\mathrm{P}$ $>0.38$ ). These results were contrary to expectations, given the conditions believed to favor grasshopper populations. Grasshopper abundance in the southern Great Plains has been reported to be strongly favored by dry years and heavy grazing (Smith 1940, Campbell et al. 1974). However, the lower abundance of grasshoppers during the 2001 drought and 


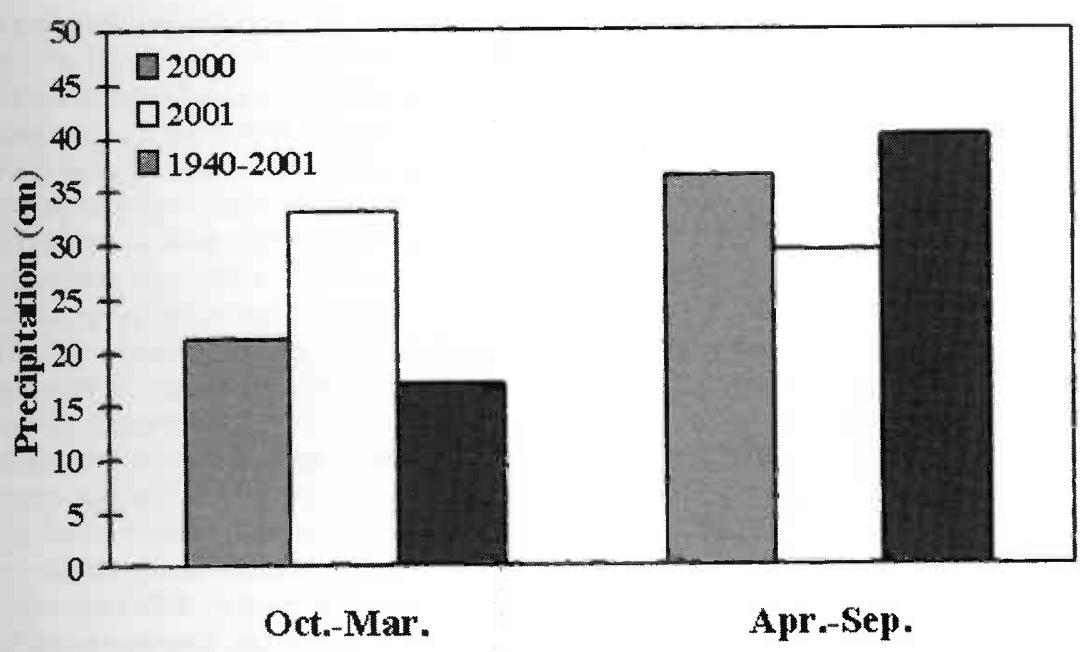

Fig. 1. Dormant (Oct.-Mar.) and growing-season (Apr.-Sep.) precipitation for Woodward, Okla. in 2000, 2001, and the 62-year mean from 1940 through 2001.

lack of burn treatment differences indicate total grasshopper abundance was unaffected by grazing pressure and may have been reduced by the drought. Despite differences in abundance, grasshopper biomass was similar between years $(\mathrm{P}>0.10)$ and among burn treatments $(\mathrm{P}>0.46)$ at 4,092 mg per 150 sweeps.

Fifteen species of grasshoppers were collected, with 4 species accounting for $83 \%$ of the individuals (Table 1 ). The most common species were Melanoplus bowditchi and $M$. flavidus, representing $61 \%$ of the grasshoppers captured. Both species were present based on males collected, but were classified as a complex because of their similar habits and the inability to distinguish between females. Ageneotettix deorum and Hesperotettix viridis were the next largest groups, representing 16 and $6 \%$ of the collection, respectively. Melanoplus bowditchi, $M$. flavidus, and $H$. viridis are forbivorous and generally considered innocuous species, but the graminivorous $A$. deorum has been ranked the fifth most detrimental grasshopper on Western rangelands (Dysart 1995).

Prescribed fire did not affect abundance of the $M$. bowditchifflavidus complex ( $\mathrm{P}>$ 0.81 , Fig. 2). Given the reproductive ecology of these species and the timing of the burns, direct mortality was unlikely. Eggs are insulated from fire by being laid deeply in the soil and nymphs do not hatch until late April or early May (Pfadt 1988). The survival and regrowth of sand sagebrush on burned plots contributed to the fire tolerance of $M$. bowditchi as well. Melanoplus bowditchi is known to forage only on plants in the genus Artemisia and the majority of its time is spent on sagebrush. Woodward, Okla. in 2000 and 2001. damaged by herbivory or water stress and populations have crashed following their own intensive herbivory on host plants (Parker 1984).

The abundance of A. deorum was $65 \%$ lower on fall-burned plots than nonburned plots ( $\mathrm{P}<0.10$, Fig. 2). Mean abundance on spring-burned plots did not differ statistically from fall- or non-burned plots $(\mathrm{P}>0.10)$. Fall burns may have reduced populations through a number of direct and indirect factors related to the reproductive ecology of $A$. deorum. Ageneotettix deorum lays its eggs horizontally near the soil surface (Pfadt 1988), leaving them more vulnerable to the heat of a passing fire than eggs of most other species. Those not killed directly by the high temperatures may have been susceptible to other sources of mortality. Eggs would have been less insulated from weather after fire temporarily removed vegetative cover and the potential movement of sandy soils following fire could leave eggs exposed on the soil surface or deeply buried. Spring burns should have had equal or greater potential for causing direct mortality than fall burns. An early spring in the southern Great Plains may allow some $A$. deorum eggs to hatch by mid-April (Pfadt 1988). Burning at this time would kill any of the wingless nymphs and potentially damage the remaining eggs. Ageneotettix deorum abundance on 1 spring-burned plot was 10 times greater than that of the other 7 plots. Areas adjacent to this plot held standing water for a period in late May and early June. Otherwise, the cause for this difference is unknown. With the exclusion of this plot, A. deorum abundance was reduced $71 \%$ by spring fires.

Table 1. Relative abundance and pest-status ranking of grasshopper species collected near

\begin{tabular}{|c|c|c|}
\hline Species & Relative abundance & Pest-status rank ${ }^{1}$ \\
\hline & $(\%)$ & \\
\hline Melanoplus bowditchi / flavidus (Scudder) ${ }^{2}$ & 60.6 & 82,70 \\
\hline Ageneotettix deorum (Scudder) & 15.8 & 5 \\
\hline Hesperotettix viridis (Scudder) & 6.4 & 377 \\
\hline Mermiria bivittata (Serville) & 5.6 & 17 \\
\hline Hippiscus ocelote (Saussure) & 3.6 & 69 \\
\hline Spharagemon cristatum (Scudder) & 2.4 & 254 \\
\hline Arphia xanthoptera (Burmeister) & 1.6 & 129 \\
\hline Melanoplus bivittatus (Say) & 1.2 & 4 \\
\hline Psinidia amplicornis (Caudell) & 0.8 & 360 \\
\hline Arphia simplex (Scudder) & 0.4 & 128 \\
\hline Chortophaga viridifasciata (DeGeer) & 0.4 & 58 \\
\hline Melanoplus sanguinipes (Fabricius) & 0.4 & 1 \\
\hline Opeia obscura (Thomas) & 0.4 & 14 \\
\hline Schistocerca obscura (Fabricius) & 0.4 & 159 \\
\hline
\end{tabular}

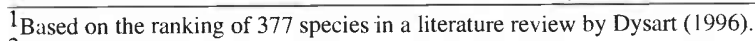

$2 M$. bowditchi and $M$. flavidus were classified as a complex because females were indistinguishable. 

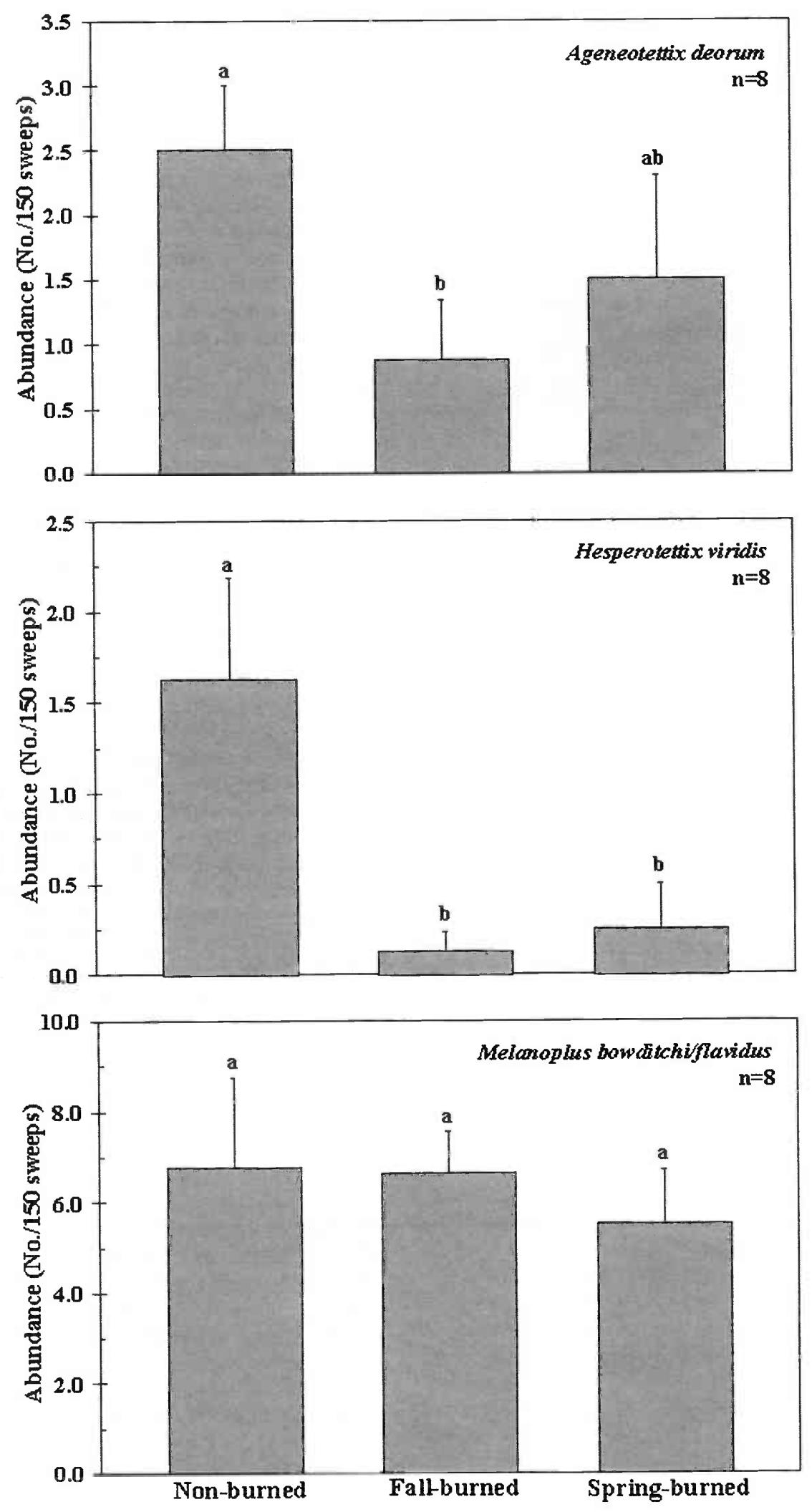

Fig. 2. Abundance of Ageneotettix deorum, Hesperotettix viridis, and a Melanoplus bowditchi/flavidus complex with standard errors on non-burned, fall-burned, and springburned sites in sand sagebrush-mixed prairie.
Fire and grazing potentially alter the timing and rate of grasshopper development. Spring fire caused hatches to occur 2 weeks earlier in Kansas tallgrass prairie because of additional soil heating (Evans 1984) and others have indicated reduced standing forage may have similar effects (Onsager 2000). Although grasshopper phenology was not directly monitored throughout the growing season, we do not believe altered hatch dates or post-hatch environment caused treatment differences in $H$. viridis and $A$. deorum abundance. Individuals within the 4 major species were developmentally similar across treatments when collected and growth stages were not apparently different during monthly vegetation surveys preceding grasshopper collection. Additionally, spring burns occurred only 1 or 2 weeks prior to the expected first hatch of $A$. deorum and expected short-term temperature differences between burned and nonburned plots were probably moderated by rapid forb growth. However, sampling throughout the spring and summer would be necessary to thoroughly address the impacts of fire and grazing on grasshopper phenology.

\section{Conclusions}

Fire is a natural phenomenon that has been shown to affect grasshopper assemblages, presumably through alterations in vegetative structure and species composition (Evans 1984, 1988). However, the influence of fire on grasshoppers is not limited to indirect effects of altering habitat. Fires can be prescribed to selectively control some grasshoppers based on unique biological characteristics. Because of the egg deposition habits of $A$. deorum, we were able to control 1 of the most detrimental grasshoppers in the western United States without reducing the overall abundance or biomass of grasshoppers. Many of the pest grasshopper species have traits that should make them vulnerable to fire. Potential pest species that overwinter as nymphs, such as Eritettix simplex (Scudder) and Xanthippus corallipes (Haldeman), could be specifically targeted by winter burns because the nymphs are relatively immobile and other species are protected in the soil as eggs. Aulocara elliotti (Thomas), ranked the second most detrimental grasshopper by Dysart (1995), lays its eggs near the soil surface like Ageneotettix deorum. The ability to kill the eggs of such species will likely depend on heat intensity and duration. Both of 
these factors are maximized if fuels are dry, abundant, and continuous at the time of burning. Possibilities also exist for indirect control of early-hatching species. Soils on burned sites typically warm earlier in the spring than non-burned sites (Wright and Bailey 1982), so fire may facilitate an early hatch and expose nymphs to latewinter and early-spring freezes.

The goals of grasshopper management programs are generally to reduce the frequency, duration, or magnitude of outbreaks by pest species. Prescribed fire may be a satisfactory alternative to insecticides that would accomplish these goals while maintaining the food base for grasshopper predators, such as gallinaceous birds. Additional research is needed to explore the possibility of prescribed fire as a control agent for pest species in other regions.

\section{Literature Cited}

Blickenstaff, C.C., F.E. Skoog, and R.J. Daum. 1974. Long-term control of grasshoppers. J. Econ. Entomol. 67:268-274.

Campbell, J.B., W. H. Arnett, J.D. Lambley, O.K. Jantz, and H. Knutson. 1974. Grasshoppers (Acrididae) of the Flint Hills native tallgrass prairie in Kansas. Kans.State Univ. Agr. Exp. Sta. Res. Paper 19. Manhattan, Kans.

Coppock, S., Jr. 1962. The grasshoppers of Oklahoma (Orthoptera: Acrididae). Okla. State Univ. Agr. Exper. Sta. Processed Series P-399. Stillwater, Okla.

Davis, C.A., RC. Barkley, and W. C. Haussamen. 1975. Scaled quail foods in southeastern New Mexico. J. Wildl. Manage. 39:496-502.

DeFoliart, G.R. 1975. Insects as a source of protein. Bull. Entomol. Soc. Amer. 21:161-163.

Doerr, T.B. and F.S. Guthery. 1983. Food selection by lesser prairie chickens in Northwest Texas. Southwestern Natur. 28:381-383.
Dysart, R.J. 1995. Relative importance of rangeland grasshoppers in western North America: a numerical ranking from the literature, pp. VI.6-1 to VI.6-20. In: Integrated Pest Management User Handbook. USDAAPHIS Tech. Bull. 1809. Washington, D.C.

Evans, E.W. 1984. Fire as a natural disturbance to grasshopper assemblages of tallgrass prairie. Oikos 43:9-16.

Evans, E.W. 1988. Grasshopper (Insecta: Orthoptera: Acrididae) assemblages of tallgrass prairie: influences of fire frequency, topography, and vegetation. Can. J. Zool. 66:1495-1501.

Fielding, D.J. and M.A. Brusven. 1990. Historical analysis of grasshopper (Orthoptera: Acrididae) population response to climate in southern Idaho. Environ. Entomol. 19:1786-1791.

George, T. L, L.C. McEwen, and B.E. Petersen. 1995. Effects of grasshopper control programs on rangeland breeding bird populations. J. Range Manage. 48:336-342.

Helfer, J.R. 1953. How to know the grasshoppers, cockroaches, and their allies. Wm. C. Brown Co., Dubuque, Iowa.

Hewitt, G.B. and J.A. Onsager. 1983. Control of grasshoppers on rangeland in the United States - a perspective. J. Range Manage. 36:202-207.

Johnson, G.D. and M.S. Boyce. 1990. Feeding trials with insects in the diet of sage grouse chicks. J. Wildl. Manage. 54:89-91.

McEwen, L.C., CE. Knittle, and M.L. Richmond. 1972. Wildlife effects from grasshopper insecticides sprayed on shortgrass prairie. J. Range Manage. 25:188-194.

Nance, E.C., C.A. Steers, E.L. Cole, M.L. Miller, and C. F. Fanning. 1960. Soil survey Woodward County, Oklahoma. USDA, Washington, D.C.

Onsager, J.A. 2000. Suppression of grasshoppers in the Great Plains through grazing management. J. Range Manage. 53:592-602.

Otte, D. 1981. North American grasshoppers Acrididae: Gomphocerinae and Acridinae.Harvard Univ. Press. Cambridge, Mass.
Otte, D. 1984. North American grasshoppers Acrididae: Oedipodinae. Harvard Univ. Press. Cambridge, Mass.

Parker, M.A. 1984. Local food depletion and the foraging behavior of a specialist grasshopper, Hesperotettix viridis. Ecol. 65:824-835.

Pfadt, R.E. 1988. Field guide to common western grasshoppers. Wyo. Agr. Exp.. Sta. Bull. 912. Laramie, Wyo.

Putnam, L.G. 1963. The progress of nymphal development in pest grasshoppers (Acrididae) of western Canada. Can. Entomol. 95:1210-1216.

SAS Institute. 1985. SAS/STAT Guide for personal computers, Version 6 edition. Cary, N.C.

Smith, C.C. 1940. The effects of overgrazing and erosion on the biota of the mixed grass prairie of Oklahoma. Ecol. 21:381-397.

Steele, R.G.D. and J.H. Torrie. 1980. Principles and procedures of statistics. McGraw-Hill Book Co., New York, N.Y.

Stromborg, K.L., L.C. McEwen, and T. Lamont. 1984. Organophosphate residues in grasshoppers from sprayed rangelands. Chem. Ecol. 2:39-45.

Ueckert, D.N., S.P. Yang, and R.C. Albin. 1972. Biological value of rangeland grasshoppers as a protein concentrate. J. Econ. Entomol. 65:1286-1288.

Vermeire, L.T. 2002. The fire ecology of sand sagebrush-mixed prairie in the Southern Great Plains. Ph.D. Diss., Texas Tech Univ. Lubbock, Tex.

Watts, J.G., G.B. Hewitt, E.W. Huddleston, H.G. Kinzer, R.J. Lavigne, and D.N. Ueckert. 1989. Rangeland Entomology. Society for Range Management, Denver, Colo.

Wright, H.A. and A.W. Bailey. 1982. Fire Ecology: United States and Southern Canada.John Wiley and Sons, Inc., New York. 